\title{
Sistem Informasi Layanan Praktikum Berbasis Web (Studi Kasus: Laboratorium Pelayanan Komputasi Jurusan Ilmu Komputer / Informatika Universitas Diponegoro)
}

\author{
Sarwo Dwi Waskito, Putut Sri Wasito, Indra Waspada \\ Jurusan Ilmu Komputer/ Informatika \\ Fakultas Sains dan Matematika Universitas Diponegoro \\ J1. Prof. Soedarto, SH, Tembalang Semarang - 50275 \\ Email: milanistito@gmail.com
}

\begin{abstract}
Abstrak
Praktikum merupakan suatu kegiatan di dalam laboratorium untuk menerapkan ilmu yang diperoleh mahasiswa dari kegiatan kuliah. Kegiatan ini diwajibkan untuk mahasiswa yang mengikuti mata kuliah tertentu di Jurusan Ilmu Komputer / Informatika Universitas Diponegoro. Beberapa kegiatan praktikum, seperti pendaftaran peserta praktikum dan pencetakan dokumen presensi, masih dilakukan secara manual. Hal ini akan menimbulkan permasalahan sehingga bisa menghambat kelancaran pelaksanaan kegiatan praktikum. Sistem Informasi Layanan Praktikum yang berbasis web dibangun untuk mempermudah dan mempercepat pengelolaan pelayanan seluruh kegiatan praktikum. Sistem Informasi ini dikembangkan dengan menggunakan kerangka kerja web engineering. Web engineering merupakan suatu proses pendekatan rekayasa yang digunakan untuk membuat sistem atau aplikasi berbasis web yang berkualitas dengan menyediakan langkah-langkah yang sesuai dengan kebutuhan sistem atau aplikasi berbasis web. Aktivitas web engineering meliputi komunikasi, perencanaan, pemodelan, pembangunan dan deployment yang dilakukan secara inkremental. Sistem informasi berbasis web ini diimplementasikan menggunakan bahasa pemrograman Java (menggunakan JSP dan Framework Struts 2) dan sistem manajemen basis data MySQL. Hasil yang didapat adalah suatu Sistem Informasi Layanan Praktikum berbasis web yang dapat membantu kelancaran proses pelaksanaan praktikum di lingkungan Jurusan Ilmu Komputer / Informatika Universitas Diponegoro.
\end{abstract}

Kata kunci: Praktikum, sistem informasi, web engineering, Framework Struts 2

\section{Pendahuluan}

Beberapa mata kuliah yang diajarkan di Jurusan Ilmu Komputer / Informatika Universitas Diponegoro mewajibkan mahasiswa yang mengikuti mata kuliah tersebut untuk mengikuti praktikum. Praktikum adalah suatu kegiatan perkuliahan yang dilaksanakan mahasiswa di dalam laboratorium. Kegiatan ini mengimplementasikan ilmu yang telah diperoleh mahasiswa dari kegiatan kuliah. Kegiatan praktikum ini dilaksanakan oleh peserta praktikum, asisten praktikum, instruktur dan pengelola praktikum. Peserta praktikum adalah mahasiswa yang mengikuti pelaksanaan praktikum suatu mata kuliah di laboratorium. Asisten praktikum adalah mahasiswa yang membantu instruktur dalam pelaksanaan praktikum di laboratorium. Instruktur adalah dosen pengampu mata kuliah praktikum. Pengelola praktikum adalah ketua laboratorium yang mengelola seluruh kegiatan praktikum mulai dari persiapan pelaksanaan praktikum hingga kegiatan pasca praktikum

Untuk mendukung kelancaran seluruh kegiatan pelaksanaan praktikum, pengelola praktikum perlu berkomunikasi dengan seluruh orang yang terlibat dalam kegiatan pelaksanaan praktikum yaitu instruktur, peserta praktikum dan asisten praktikum. Bentuk komunikasi ini misalnya berupa pengumuman-pengumuman terkait dengan kegiatan pelaksanaan praktikum. Jika komunikasi yang dilakukan tidak direspon dengan cepat maka akan menghambat kelancaran kegiatan praktikum.

Mahasiswa yang akan mengikuti kegiatan praktikum suatu mata kuliah diharuskan mendaftar sebagai peserta praktikum. Mahasiswa mengisi suatu formulir pendaftaran peserta praktikum yang telah disediakan oleh pengelola. Kegiatan pendaftaran peserta praktikum ini belum dilakukan secara otomatis sehingga akan muncul permasalahan seperti jumlah mahasiswa yang mendaftar sebagai 
peserta praktikum untuk suatu kelas bisa melebihi kapasitas ruang laboratorium.

Administrasi praktikum seperti dokumen presensi peserta praktikum juga masih belum diproses secara otomatis, sehingga sering terjadi kesalahan pada daftar peserta praktikum yang tertera di dokumen presensi tersebut. Dengan adanya suatu sistem yang telah terotomatisasi diharapkan akan mengurangi kesalahan yang terjadi sehingga data-data yang diproses akan menjadi lebih akurat.

Untuk mengatasi berbagai permasalahan tersebut, dibutuhkan suatu sistem informasi layanan praktikum berbasis web untuk mempermudah dan mempercepat pengelolaan pelayanan seluruh kegiatan praktikum sehingga mampu mendukung kelancaran seluruh kegiatan pelaksanaan praktikum. Sistem informasi ini juga diharapkan mampu menyajikan data-data terkait kegiatan praktikum secara akurat. Sistem informasi berbasis web dipilih untuk pengembangan sistem informasi ini agar memudahkan penggunanya dalam mengakses sistem informasi ini.

Sistem informasi layanan praktikum berbasis web ini akan dikembangkan dengan menggunakan pendekatan web engineering. Sistem informasi atau aplikasi yang berbasis web memiliki beberapa perbedaan karakteristik dengan perangkat lunak konvensional sehingga memerlukan pendekatan rekayasa khusus dalam mengembangkan sistem informasi atau aplikasi berbasis web. Web engineering adalah pendekatan rekayasa khusus yang menyediakan sebuah kerangka kerja untuk membuat sistem atau aplikasi berbasis web berkualitas baik.

\section{Tinjauan Pustaka}

Bagian ini membahas tentang dasar teori dan pustaka yang digunakan.

\subsection{Sistem Informasi}

Sistem adalah sekumpulan komponen yang saling berhubungan dan bekerja sama untuk mencapai suatu tujuan, sedangkan informasi merupakan proses lebih lanjut dari data dan memiliki nilai tambah. Sistem Informasi dapat didefinisikan sebagai suatu sistem yang dibuat oleh manusia yang terdiri dari komponen-komponen dalam organisasi untuk mencapai suatu tujuan yaitu menyajikan informasi. Sistem informasi memiliki sejumlah komponen yaitu manusia, data, prosedur, perangkat keras dan perangkat lunak. Di dalam suatu sistem informasi terdapat beberapa kegiatan yang mencakup input, proses, output, penyimpanan dan kontrol. [1]

\subsection{Aplikasi Berbasis Web}

Aplikasi berbasis web adalah suatu perangkat lunak yang menyediakan suatu informasi yang distrukturisasi agar memiliki arti dan dibangun pada sebuah paket presentasi yang teroganisasi, estetis, ergonomis dan interaktif yang dikirimkan ke web browser untuk ditampilkan dan digunakan oleh pengguna. Kombinasi aplikasi berbasis web dengan perangkat keras untuk client dan server, sistem operasi, perangkat lunak jaringan dan web browser akan membentuk suatu sistem berbasis web. Aplikasi atau sistem berbasis web yang dikembangkan telah menjangkau berbagai aspek seperti bisnis, komersial, komunikasi, pendidikan, teknik, hiburan, finansial, pemerintahan, industri, media, kedokteran, politik, sains dan transportasi. [2]

Aplikasi berbasis web memiliki karakteristik yang berbeda dengan perangkat lunak konvensional. Sehingga pengembangan aplikasi berbasis web harus dilakukan dengan pendekatan rekayasa khusus yang berbeda dengan pendekatan rekayasa perangkat lunak konvensional.

\subsection{Web Engineering}

Web engineering atau rekayasa web adalah suatu proses pendekatan rekayasa yang digunakan untuk membuat sistem dan aplikasi berbasis web yang berkualitas. Menurut Pressman, web engineering menyediakan sebuah kerangka kerja secara agile yang memiliki aturan-aturan untuk membangun aplikasi berbasis web berkualitas industri. Sifat agile pada web engineering mampu mengakomodasi perubahan cepat dan berkelanjutan saat mengembangkan aplikasi berbasis web. Kerangka kerja yang digunakan web engineering menggunakan kerangka kerja umum rekayasa perangkat lunak yang aktivitasnya meliputi 
komunikasi, perencanaan, pemodelan, pembangunan dan deployment. [2]

Tahap komunikasi meliputi tiga tahapan yaitu tahap formulasi konteks bisnis, tahap penggambaran kebutuhan aplikasi berbasis web dan tahap perundingan antara pengembang dengan pengguna. Tahap perencanaan meliputi pembuatan jadwal pengembangan, penanganan resiko, menentukan tingkat kualitas dan perencanaan produk kerja yang akan dihasilkan. Tahap pemodelan meliputi analisis dan perancangan. Tahap pembangunan meliputi implementasi dan pengujian. Tahap deployment meliputi pengiriman aplikasi berbasis web dan evaluasi dari pengguna.

Web engineering menekankan pada tiga poin dalam pengembangan suatu sistem dan aplikasi berbasis web yaitu rilis aplikasi secara inkremental (incremental delivery), perubahan pada aplikasi yang terus berlanjut (continuous change) dan timeline yang pendek (short timeline). Aplikasi berbasis web dikembangkan secara inkremental dimana pada setiap inkremen, pelanggan menentukan kebutuhan yang akan ditambahkan pada inkremen selanjutnya. Alur proses akan terus diulang setiap inkremen. Aplikasi berbasis web memiliki karakteristik mampu terus berubah secara berkelanjutan. Perubahan ini merupakan evaluasi pelanggan dari inkremen sebelumnya atau merupakan konsekuensi perubahan bisnis aplikasi berbasis web. Pengembangan aplikasi berbasis web juga harus dilakukan dalam waktu yang singkat agar mampu mengakomodasi perubahan aplikasi berbasis web yang secara berkelanjutan. [2]

\subsection{Konsep Object-oriented}

Konsep pengembangan sistem informasi ini menggunakan konsep object-oriented. Konsep ini berdasar pada kumpulan objek yang masing-masing memiliki attribute dan behavior. Dalam konsep berorientasi objek, objek digambarkan dalam suatu class. Konsep objectoriented memiliki beberapa prinsip utama yaitu enkapsulasi, inheritance dan polymorphism. [3]

\subsection{Unified Modeling Language (UML)}

Unified Modeling Language (UML) adalah bahasa dan notasi yang digunakan untuk menggambarkan model spesifikasi, konstruksi, visualisasi dan dokumentasi suatu perangkat lunak yang akan dikembangkan. UML diperkenalkan dan dijadikan standar oleh Object Management Group (OMG) dibawah arahan Grady Booch, Ivar Jacobson dan James Rumbaugh. [4]

\subsection{Teknologi Pengembangan Web}

Sistem informasi ini dikembangkan dengan menggunakan Java dan MySQL. Java digunakan untuk implementasi sistem sedangkan MySQL adalah sistem manajemen basis data yang digunakan sistem informasi ini. Teknologi Java yang digunakan untuk implementasi sistem informasi ini adalah Java Server Pages (JSP) dan Framework Struts 2.

Java Server Pages (JSP) merupakan sebuah teknologi yang dikembangkan oleh Sun Microsystems untuk memisahkan konten halaman web dinamis dengan desain halaman statis HTML. JSP mirip dengan bahasa pemrograman PHP yang merupakan bahasa server-side scripting yang bekerja di sisi server. JSP menyediakan kemampuan untuk menampilkan konten dinamis halaman web. Dengan adanya pemisahan desain halaman statis dengan konten halaman web dinamis ini, desain halaman web dapat diubah-ubah tanpa harus mengubah bagian konten halaman web dinamis. [5]

Apache Struts 2 atau Struts 2 adalah generasi kedua framework aplikasi web yang mengimplementasikan pola MVC (Model-ViewController). Tujuan dikembangkannya Apache Struts adalah untuk memetakan pola MVC dari aplikasi berbasis desktop ke sebuah kerangka kerja aplikasi berbasis web. Hasil pemetaan ini dinamakan dengan pola Model 2. Apache Struts 2 adalah pengembangan dari framework Apache Struts 1 yang memiliki banyak keterbatasan. Struts 2 menyediakan framework yang lebih bersih dan fleksibel dibandingkan Struts 1. [6]

Struts 2 mengimplementasikan pola MVC. Pola MVC terdiri dari tiga buah modul yaitu model, view dan controller. Dalam Struts 2, model diimplementasikan sebagai action, view diimplementasikan sebagai result dan controller diimplementasikan sebagai filter dispatcher.

MySQL merupakan sistem manajemen basis data yang populer digunakan. MySQL 
dikembangkan, didistribusi dan didukung oleh MySQL AB dengan konsep open source dan tersedia untuk berbagai sistem operasi. Beberapa pengembang suatu aplikasi memilih bahasa Java sebagai bahasa pemrograman aplikasi tersebut dengan MySQL sebagai DBMS-nya. Agar aplikasi dalam bahasa pemrograman Java yang dikembangkan dapat berkomunikasi dengan DBMS relasional seperti MySQL, digunakan suatu antarmuka standar dari Java yang dinamakan JDBC. JDBC adalah application programming interface (API) untuk memanipulasi basis data. [7]

\section{Pembahasan}

Pembahasan meliputi tahap definisi kebutuhan, perencanaan, pemodelan, pembangunan dan deployment.

\subsection{Definisi Kebutuhan}

Sistem Informasi Layanan Praktikum adalah sistem informasi berbasis web yang dirancang untuk membantu mengelola pelaksanaan kegiatan praktikum di Jurusan Ilmu Komputer / Informatika Universitas Diponegoro mulai dari persiapan pelaksanaan, saat pelaksanaan dan pasca pelaksanaan praktikum. Tujuan sistem informasi ini adalah untuk memudahkan dan mempercepat penggunanya dalam mengelola pelaksanaan kegiatan praktikum, mengotomatisasi beberapa kegiatan praktikum dan menyajikan data yang akurat terkait dengan kegiatan praktikum sehingga mendukung kelancaran kegiatan praktikum.

Sistem informasi ini memiliki empat pengguna yaitu administrator, instruktur, mahasiswa dan pengunjung. Administrator adalah pengelola praktikum yang memiliki tanggung jawab dalam mengelola seluruh kegiatan praktikum. Instruktur adalah dosen pengampu yang memiliki tugas mengelola beberapa kegiatan praktikum antara lain mengusulkan praktikum untuk mata kuliah yang diampunya, memberikan pengarahan ketika praktikum sedang berjalan, menyeleksi asisten praktikum mata kuliah yang diampunya dan mengolah nilai peserta praktikum. Mahasiswa adalah peserta didik yang dapat menjadi peserta praktikum atau asisten praktikum. Pengunjung adalah orang-orang yang mengunjungi sistem informasi ini tanpa melakukan login ke dalam sistem.

Tahap awal kerangka kerja web engineering adalah tahap komunikasi dimana kebutuhan sistem informasi ini didefinisikan. Definisi kebutuhan Sistem Informasi Layanan Praktikum digambarkan dengan model use case. Use case sistem informasi layanan praktikum terdiri dari 31 use case antara lain:

- Login pengguna

- Mengubah kata sandi pengguna

- Mengelola tahun ajaran

- Mengelola data mata kuliah

- Mengelola data instruktur

- Mengelola data instruktur mata kuliah

- Mengelola data mahasiswa

- Mengelola data peserta mata kuliah

- Mengusulkan praktikum

- Menyetujui usulan praktikum

- Mengelola data pengguna

- Mengelola data hari praktikum

- Mengelola data jam praktikum

- Mengelola data ruang praktikum

- Mengelola data kelas praktikum

- Mengelola jadwal praktikum

- Mengelola berkas modul

- Melakukan pencarian berkas modul

- Mengunduh berkas modul

- Mendaftar sebagai peserta

- Mendaftar sebagai asisten

- Menyeleksi asisten praktikum

- Mengelola pernyataan asisten praktikum

- Mencetak dokumen presensi

- Meminta penggantian jadwal

- Melakukan konfirmasi permintaan penggantian jadwal

- Memberi nilai peserta praktikum

- Mengolah masukan nilai peserta

- Mengirim pesan

- Mengelola berita praktikum

- Mengubah alamat email pengguna

\subsection{Perencanaan}

Tahap selanjutnya adalah tahap perencanaan. Tahap perencanaan pengembangan sistem informasi ini meliputi identifikasi rencana per inkremen dan pembuatan jadwal pengembangan keseluruhan sistem informasi ini.

Setiap use case yang telah diidentifikasi sebelumnya diberi suatu indikator tingkat kesulitan 
atau disebut indikator usaha (effort indicator) untuk mendefinisikan perkiraan tingkat kesulitan pengerjaan fungsi untuk tiap use case. Indikator yang akan digunakan berkisar antara angka 1 hingga 4. Angka 1 untuk yang paling mudah, sementara angka 4 untuk yang paling sulit. Alokasi indikator usaha untuk setiap use case ditunjukkan pada tabel.1.

Tabel 1. Alokasi indikator usaha untuk tiap use case

\begin{tabular}{|c|c|c|}
\hline No. & Use Case & $\begin{array}{c}\text { Indikator } \\
\text { Usaha }\end{array}$ \\
\hline 1. & Login Pengguna & 2 \\
\hline 2. & $\begin{array}{l}\text { Mengubah kata sandi } \\
\text { pengguna }\end{array}$ & 1 \\
\hline 3. & Mengelola tahun ajaran & 1 \\
\hline 4. & Mengelola data mata kuliah & 2 \\
\hline 5. & Mengelola data instruktur & 1 \\
\hline 6. & $\begin{array}{l}\text { Mengelola data instruktur } \\
\text { mata kuliah }\end{array}$ & 1 \\
\hline 7. & Mengelola data mahasiswa & 1 \\
\hline 8. & $\begin{array}{l}\text { Mengelola data peserta } \\
\text { mata kuliah }\end{array}$ & 1 \\
\hline 9. & Mengusulkan praktikum & 1 \\
\hline 10. & $\begin{array}{l}\text { Menyetujui usulan } \\
\text { praktikum }\end{array}$ & 1 \\
\hline 11. & Mengelola data pengguna & 1 \\
\hline 12. & $\begin{array}{l}\text { Mengelola data hari } \\
\text { praktikum }\end{array}$ & 1 \\
\hline 13. & $\begin{array}{l}\text { Mengelola data jam } \\
\text { praktikum }\end{array}$ & 1 \\
\hline 14. & $\begin{array}{l}\text { Mengelola data ruang } \\
\text { praktikum }\end{array}$ & 1 \\
\hline 15. & $\begin{array}{l}\text { Mengelola data kelas } \\
\text { praktikum }\end{array}$ & 1 \\
\hline 16. & $\begin{array}{l}\text { Mengelola jadwal } \\
\text { praktikum }\end{array}$ & 1 \\
\hline 17. & Mengelola berkas modul & 3 \\
\hline 18. & $\begin{array}{l}\text { Melakukan pencarian } \\
\text { berkas modul }\end{array}$ & 1 \\
\hline 19. & Mengunduh berkas modul & 1 \\
\hline 20. & Mendaftar sebagai peserta & 2 \\
\hline 21. & Mendaftar sebagai asisten & 2 \\
\hline 22. & $\begin{array}{l}\text { Menyeleksi asisten } \\
\text { praktikum }\end{array}$ & 1 \\
\hline 23. & $\begin{array}{l}\text { Mengelola pernyataan } \\
\text { asisten praktikum }\end{array}$ & 1 \\
\hline 24. & Mencetak dokumen & 4 \\
\hline
\end{tabular}

\begin{tabular}{|l|l|c|}
\hline 25. & $\begin{array}{l}\text { presensi } \\
\text { jadwal }\end{array}$ & 2 \\
\hline 26. & $\begin{array}{l}\text { Melakukan konfirmasi } \\
\text { permintaan penggantian } \\
\text { jadwal }\end{array}$ & 2 \\
\hline 27. & $\begin{array}{l}\text { Memberi nilai peserta } \\
\text { praktikum }\end{array}$ & 2 \\
\hline 28. & $\begin{array}{l}\text { Mengolah masukan nilai } \\
\text { peserta }\end{array}$ & 3 \\
\hline 29. & Mengirim pesan & 1 \\
\hline 30 & Mengelola berita praktikum & 1 \\
\hline 31. & $\begin{array}{l}\text { Mengubah alamat email } \\
\text { pengguna }\end{array}$ & 45 \\
\hline & Total Indikator Usaha: & \\
\hline
\end{tabular}

Pengembangan Sistem Informasi Layanan Praktikum dibagi menjadi tiga inkremen. Inkremen ini disusun berdasarkan urutan kegiatan praktikum. perencanaan inkremen pengembangan Sistem Informasi Layanan Praktikum ditunjukkan pada tabel 2.

Tabel 2. Perencanaan iterasi pengembangan Sistem Informasi Layanan Praktikum

\begin{tabular}{|c|l|c|c|}
\hline $\begin{array}{c}\text { Inkre } \\
\text { men }\end{array}$ & \multicolumn{1}{|c|}{ Deskripsi } & $\begin{array}{c}\text { Nomor } \\
\text { use case }\end{array}$ & $\begin{array}{c}\text { Total } \\
\text { indikato } \\
\text { r usaha }\end{array}$ \\
\hline 1 & $\begin{array}{l}\text { Kegiatan pra- } \\
\text { praktikum } \\
\text { hingga } \\
\text { pembuatan } \\
\text { jadwal } \\
\text { praktikum }\end{array}$ & $1-16$ & 18 \\
\hline 2 & $\begin{array}{l}\text { Kegiatan pra- } \\
\text { praktikum } \\
\text { setelah } \\
\text { pembuatan } \\
\text { jadwal } \\
\text { praktikum } \\
\text { hingga } \\
\text { pencetakan } \\
\text { dokumen } \\
\text { presensi }\end{array}$ & $17-24$ & 15 \\
\hline 3 & $\begin{array}{l}\text { Kegiatan saat } \\
\text { pelaksanaan dan } \\
\text { pasca } \\
\text { pelaksanaan } \\
\text { praktikum }\end{array}$ & $25-31$ & 12 \\
\hline
\end{tabular}


Indikator usaha yang telah ditentukan untuk setiap use case kemudian dialokasikan ke dalam suatu timeline. Timeline yang digunakan adalah jadwal makroskopis yang mencakup keseluruhan iterasi yang dikerjakan untuk pengembangan sistem informasi ini. Rencana pengembangan inkremen pertama dilaksanakan selama empat minggu, inkremen kedua selama empat minggu dan inkremen ketiga selama tiga minggu.

\subsection{Pemodelan}

Tahap selanjutnya adalah tahap pemodelan. Tahap pemodelan meliputi analisis, perancangan dan pemodelan data.

Tahap analisis dalam kerangka kerja web engineering meliputi analisis konten, analisis interaksi, analisis fungsi dan analisis konfigurasi.

Pada tahap analisis konten, dari masingmasing use case yang telah ditentukan, konten yang akan disediakan oleh Sistem Informasi Layanan Praktikum diekstrak dari skenario awal use case. Konten yang diekstrak menggambarkan kelas analisis sistem informasi ini. Setiap kelas analisis diidentifikasi atribut dan operasinya. Seluruh kelas analisis yang telah diidentifikasi untuk seluruh use case kemudian digambarkan ke dalam suatu diagram kelas analisis. Diagram kelas analisis Sistem Informasi Layanan Praktikum secara keseluruhan ditunjukkan pada gambar 1 .

Pada tahap analisis interaksi, skenario use case yang lebih detail dan prototipe antarmuka pengguna dibuat untuk menggambarkan interaksi antara aktor dengan sistem informasi ini. Skenario use case yang lebih detail dan prototipe antarmuka pengguna dipilih untuk menggambarkan model interaksi karena cukup untuk menggambarkan keseluruhan interaksi antara aktor dengan Sistem Informasi Layanan Praktikum.

Model interaksi untuk use case Menyeleksi Asisten Praktikum dapat dilihat pada tabel 3. Prototipe antarmuka pengguna use case Menyeleksi Asisten Praktikum dapat dilihat pada gambar 2.

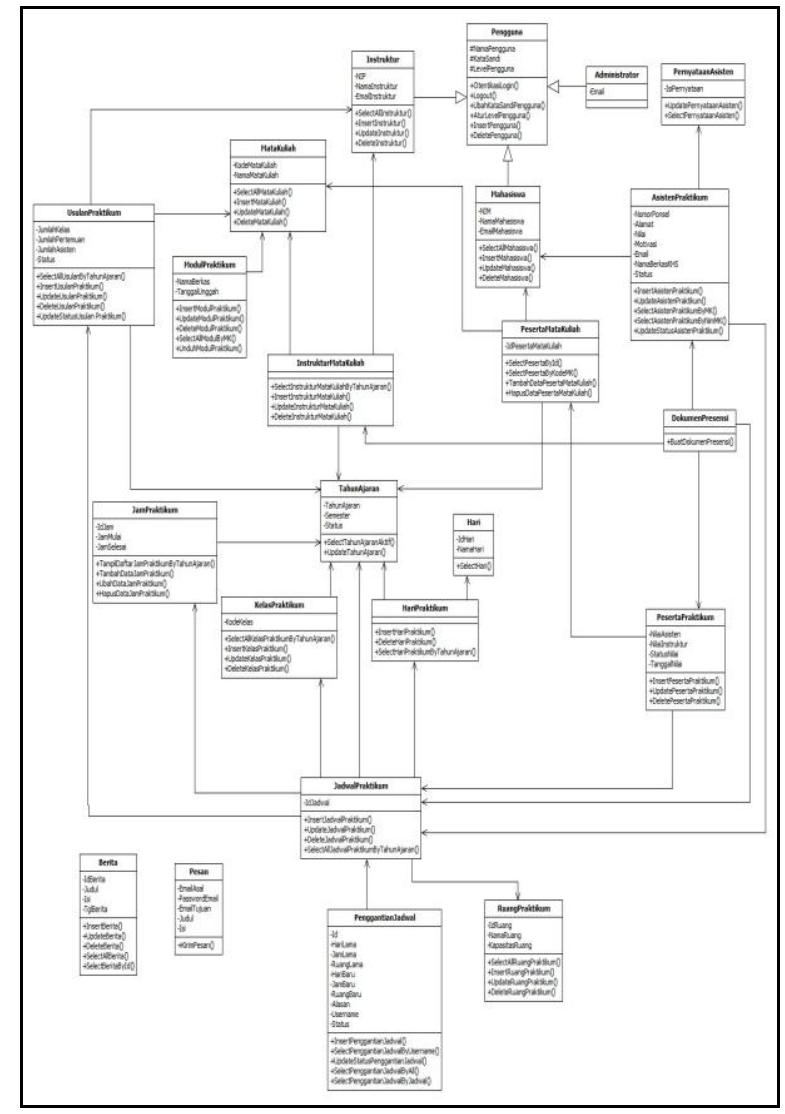

Gambar 1. Diagram kelas analisis Sistem Informasi Layanan Praktikum

Tabel 3. Model interaksi use case Menyeleksi Asisten Praktikum

\begin{tabular}{|l|}
\hline UC22: Menyeleksi Asisten Praktikum \\
\hline Aktor: \\
Administrator, Instruktur \\
\hline Tujuan: \\
Mengubah status persetujuan calon asisten \\
praktikum yang sudah mendaftar \\
\hline Kondisi Awal: \\
Aktor telah masuk ke Sistem Informasi \\
Layanan Praktikum \\
\hline Skenario Utama: \\
1. Aktor menekan tautan menuju ke \\
pengelolaan asisten praktikum di menu \\
utama administrator, \\
2. Sntuk sistem \\
menampilkan seluruh data mata kuliah \\
yang telah masuk beserta asisten \\
praktikumnya masing-masing. Untuk \\
instruktur, sistem akan menampilkan \\
data mata kuliah yang diampu instruktur \\
beserta asisten praktikumnya masing- \\
\hline
\end{tabular}


masing

3. Aktor memilih salah satu asisten untuk melihat data yang dimasukkan. Aktor juga memiliki opsi untuk mengunduh berkas KHS calon asisten yang bersangkutan.

4. Aktor memilih untuk menerima atau menolak calon asisten tersebut dengan menekan tombol 'Terima' atau 'Tolak'

5. Sistem akan menampilkan pesan bahwa status asisten praktikum yang bersangkutan telah diubah sesuai dengan pilihan aktor

\section{Kondisi Akhir:}

Status asisten praktikum berhasil diubah jika skenario berhasil dilaksanakan

\section{Skenario Abnormal:}

Sistem akan menampilkan pesan kesalahan jika status asisten praktikum gagal diubah

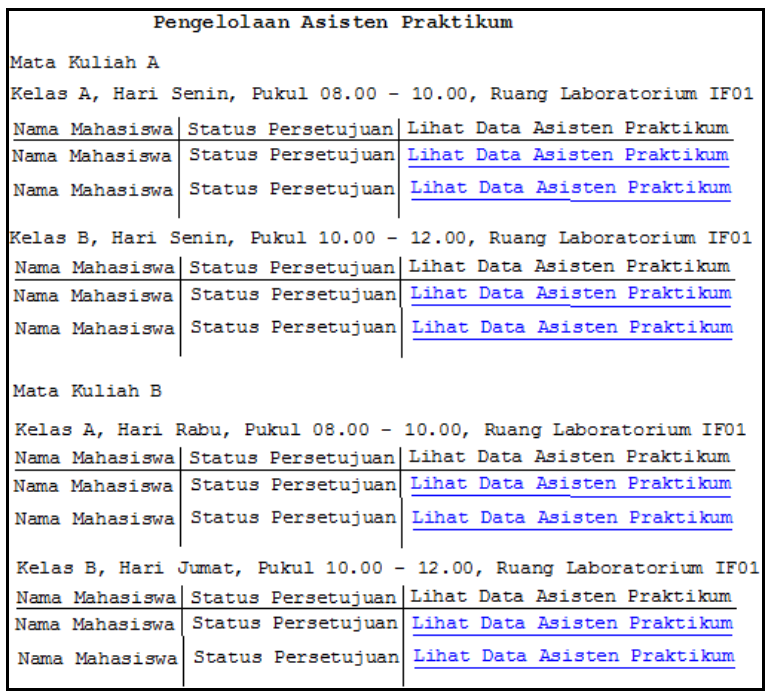

Gambar 2. Prototipe antarmuka pengguna use case Menyeleksi asisten praktikum

Pada tahap analisis fungsi, fungsi-fungsi yang akan disediakan oleh Sistem Informasi Layanan Praktikum perlu dilakukan analisis. Beberapa fungsi telah teridentifikasi pada tahap analisis konten. yaitu fungsi-fungsi yang ada pada kelas analisis.

Misal pada use case Mengelola Berkas Modul, salah satu fungsi yang teridentifikasi pada use case ini adalah fungsi Menambah Berkas Modul. Fungsi Menambah Berkas Modul memiliki pemrosesan yang cukup kompleks sehingga fungsi tersebut digambarkan ke dalam suatu activity diagram seperti pada gambar 3 .

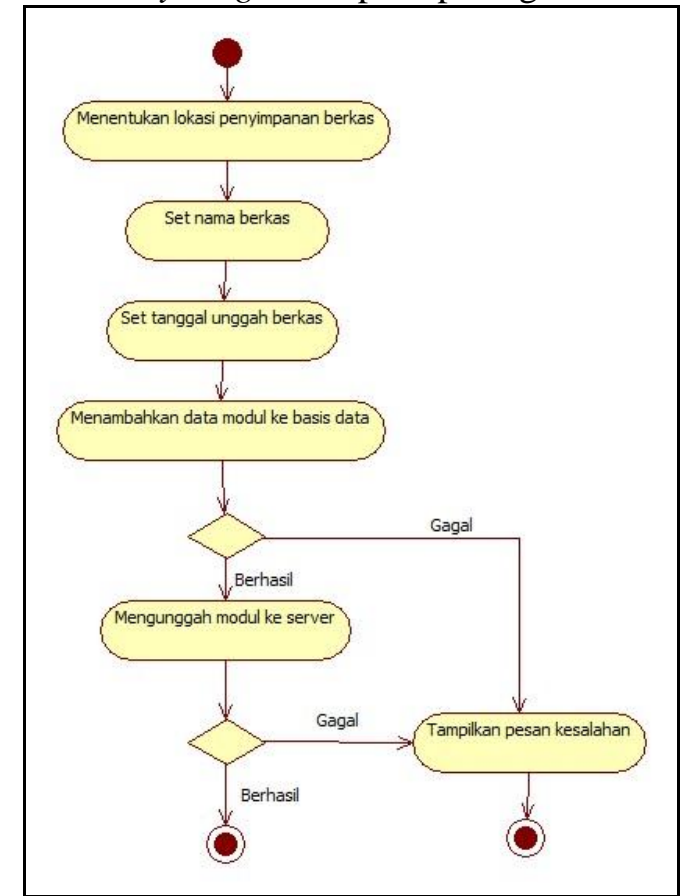

Gambar 3. Activity diagram fungsi Menambah Berkas Modul

Tahap terakhir pada tahap analisis adalah analisis konfigurasi. Konfigurasi untuk Sistem Informasi Layanan Praktikum dianalisis baik di sisi server maupun di sisi client. Berikut adalah hasil analisis konfigurasi Sistem Informasi Layanan Praktikum:

1. Server

Sistem informasi ini dibangun menggunakan bahasa Java dengan menggunakan framework Struts 2, sehingga dibutuhkan web container berbasis Java seperti Apache Tomcat untuk menjalankan sistem informasi ini. Selain itu, perangkat lunak sistem manajemen basis data yang digunakan untuk sistem informasi ini adalah MySQL.

2. Client

Sistem informasi ini dapat diakses dengan menggunakan web browser populer yang banyak digunakan seperti Firefox, Opera, Chrome atau Internet Explorer.

Setelah melakukan analisis, tahap selanjutnya adalah tahap perancangan. Tahap perancangan dalam kerangka kerja web 
engineering meliputi perancangan interaksi, perancangan informasi, perancangan fungsi dan perancangan teknis.

Perancangan interaksi meliputi perancangan antarmuka dan perancangan grafis. Gambar 4 menunjukkan hasil perancangan antarmuka, sedangkan gambar 5 menunjukkan hasil perancangan grafis yang diterapkan pada antarmuka halaman utama sistem informasi ini.

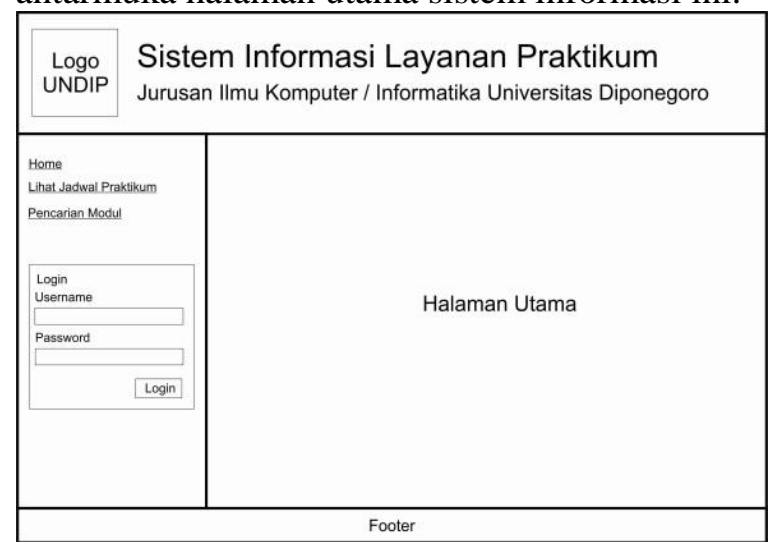

Gambar 4. Rancangan antarmuka pengguna Sistem Informasi Layanan Praktikum

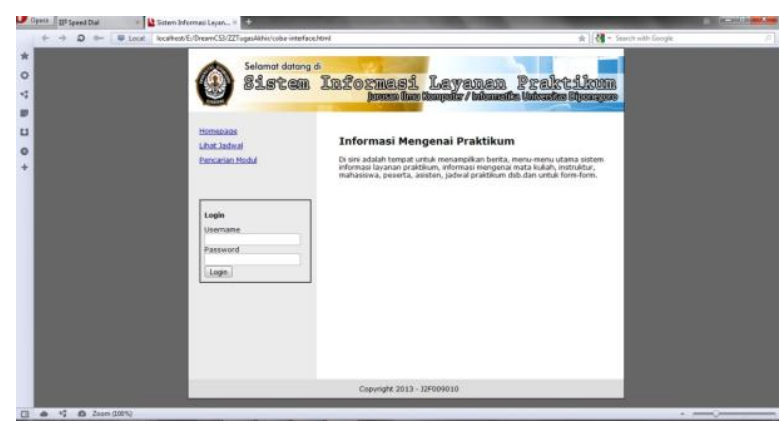

Gambar 5. Hasil perancangan grafis terhadap rancangan antarmuka halaman utama Sistem Informasi Layanan Praktikum

Setelah merancang antarmuka, tahap selanjutnya adalah tahap perancangan informasi. Perancangan informasi meliputi perancangan konten dan perancangan navigasi. Perancangan konten dan navigasi digambarkan dengan menggunakan sketsa arsitektur informasi yang menggambarkan struktur dan organisasi informasi atau konten yang disajikan sistem informasi yang dikembangkan. Sketsa arsitektur informasi pada sistem informasi ini dapat dilihat pada gambar 6.

Tahap selanjutnya adalah tahap perancangan fungsi. Dari sketsa arsitektur informasi yang telah dibuat pada tahap perancangan informasi, dibangun rancangan fungsi yang menggambarkan alur navigasi detail untuk setiap struktur dan organisasi informasi beserta fungsi-fungsi yang dibutuhkan. Gambar 7 menunjukkan rancangan fungsi untuk Pendaftaran Asisten Praktikum pada Sistem Informasi Layanan Praktikum.

Tahap perancangan selanjutnya adalah perancangan teknis. Perancangan teknis meliputi perancangan arsitektur dan perancangan kelas.

Dari analisis konfigurasi yang telah dilakukan, dibangun suatu rancangan arsitektur untuk Sistem Informasi Layanan Praktikum. Gambar 8 menunjukkan rancangan arsitektur Sistem Informasi Layanan Praktikum.

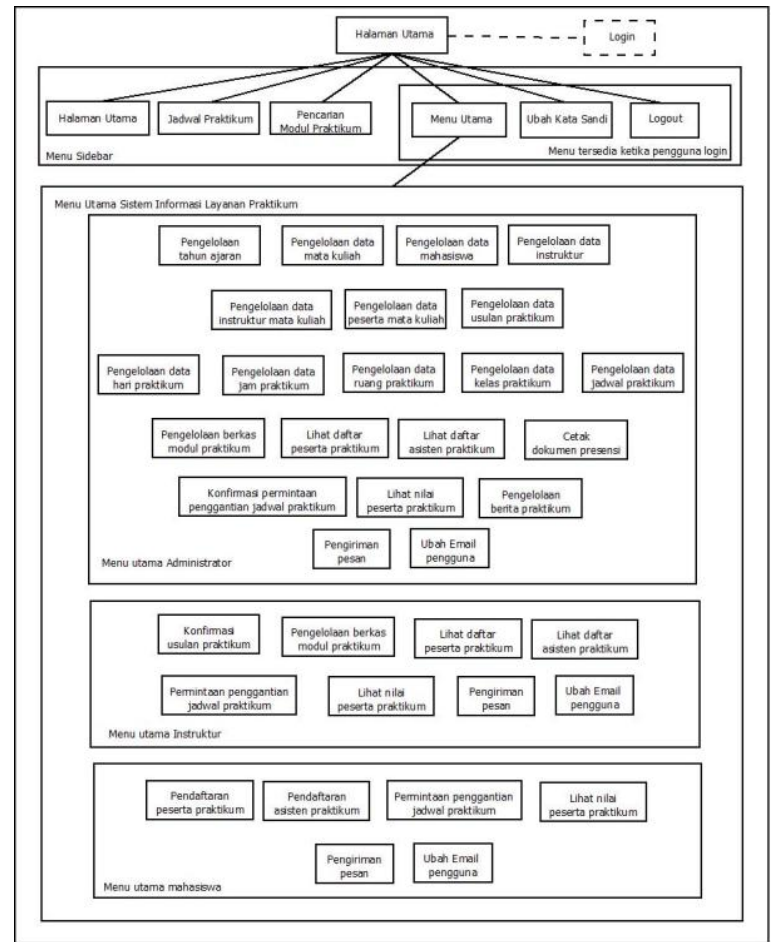

Gambar 6. Sketsa arsitektur informasi Sistem Informasi Layanan Praktikum

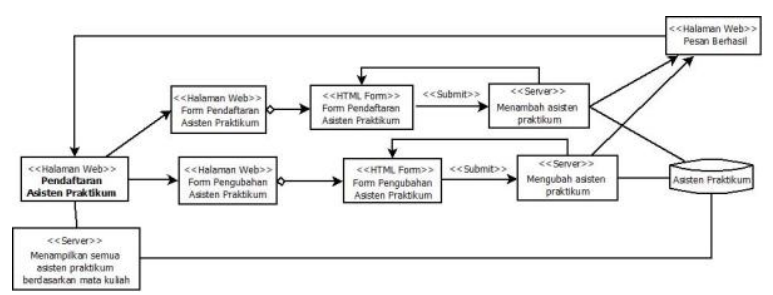

Gambar 7. Perancangan fungsi Pendaftaran Asisten Praktikum 


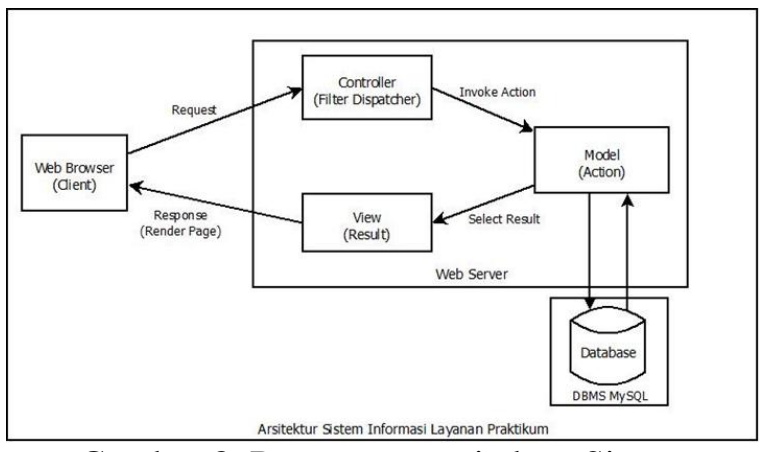

Gambar 8. Rancangan arsitektur Sistem Informasi Layanan Praktikum

Setelah merancang arsitektur Sistem Informasi Layanan Praktikum, tahap selanjutnya adalah membuat kelas perancangan. Hasil dari perancangan kelas ini adalah kelas perancangan yang akan digunakan untuk implementasi Sistem Informasi Layanan Praktikum.

Kelas analisis yang telah dibangun diekstrak menjadi kelas entitas, kemudian ditambahkan kelas-kelas yang digunakan untuk mengimplementasikan fungsi-fungsi yang telah didefinisikan pada tahap analisis fungsi, seperti kelas Data Access Object (DAO) yang digunakan untuk mengenkapsulasi fungsi-fungsi akses ke tabel-tabel yang ada pada basis data dan mengelola koneksi dengan basis data untuk mendapatkan atau menyimpan data, serta kelaskelas yang digunakan untuk mendukung kelaskelas tersebut, seperti kelas database. Gambar 9 menunjukkan diagram kelas perancangan kelas entitas, sedangkan gambar 10 menunjukkan diagram kelas perancangan kelas DAO dan kelas Database. 


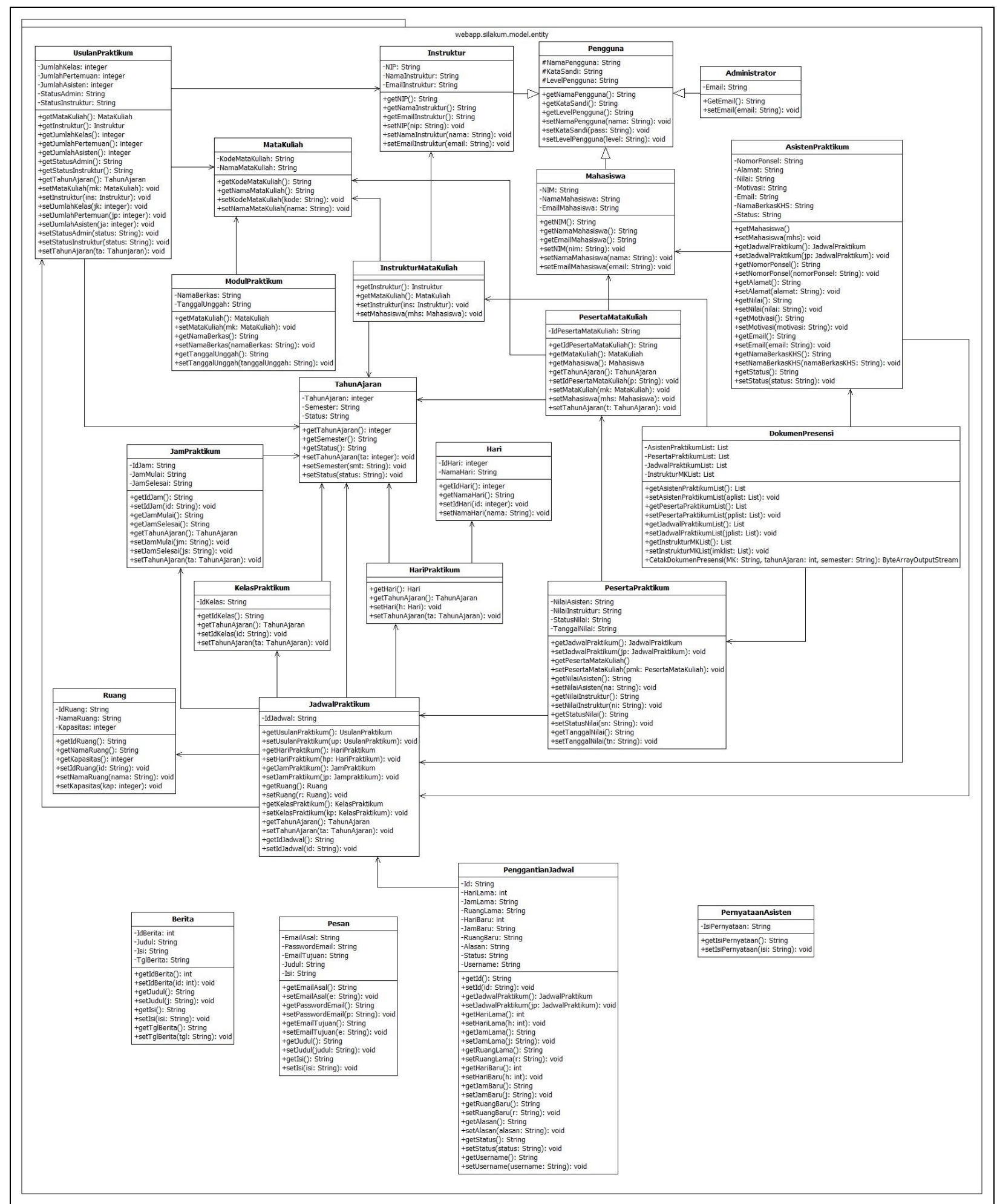

Gambar 9. Diagram kelas perancangan kelas-kelas entitas 


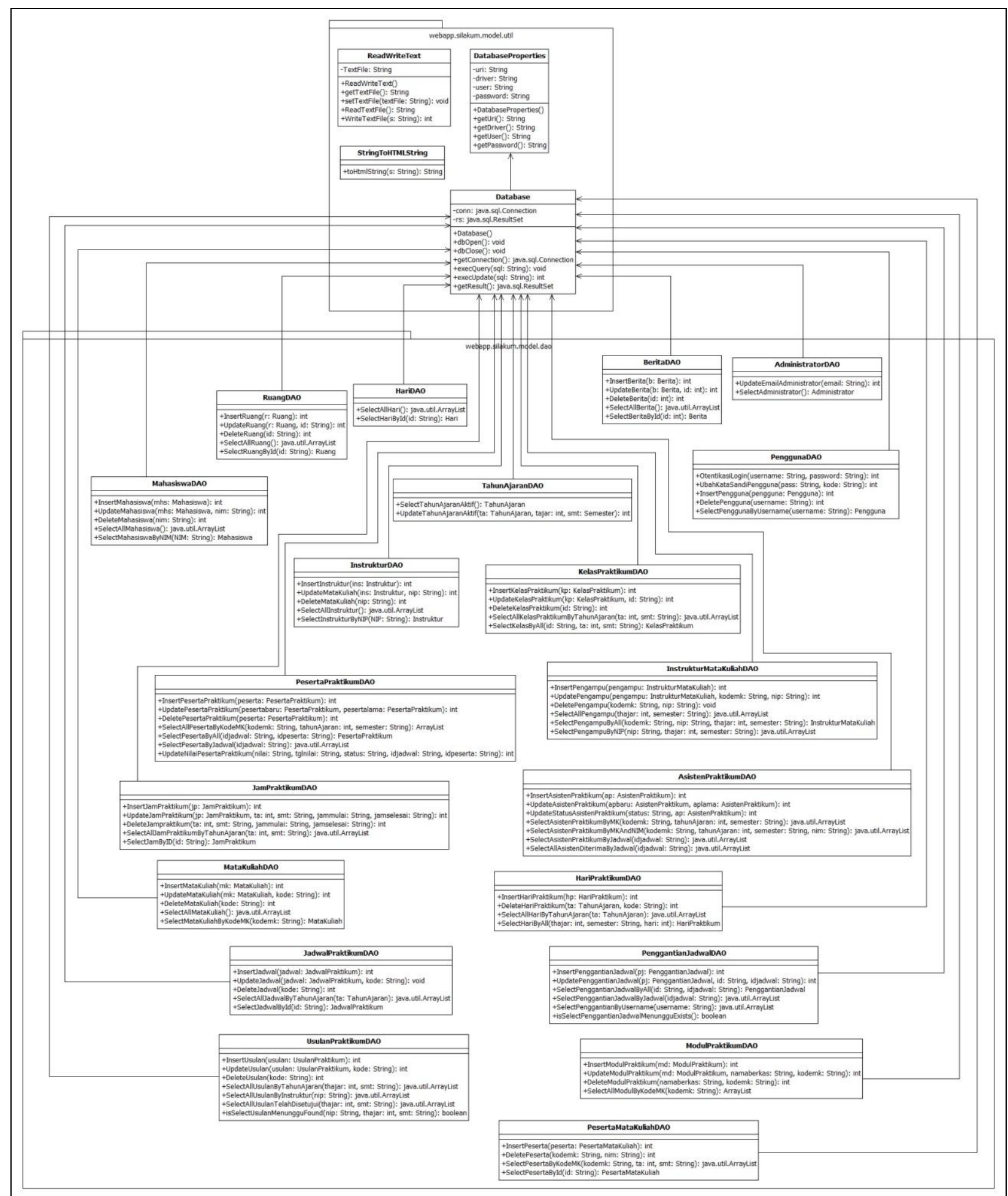

Gambar 10. Diagram kelas perancangan kelas-kelas DAO dan kelas Database

\subsection{Pembangunan}

pemodelan, tahap selanjutnya dalam kerangka kerja web engineering adalah tahap pembangunan. Tahap pembangunan meliputi implementasi pengujian.

Pada tahap implementasi, implementasi yang dilakukan meliputi implementasi class,
Setelah

melakukan

tahap implementasi basis data dan implementasi antarmuka.

Implementasi class dilakukan sesuai dengan perancangan diagram kelas perancangan. Setiap class yang teridentifikasi pada diagram kelas 
perancangan diimplementasikan ke dalam sistem informasi yang dikembangkan.

Implementasi basis data dilakukan dengan melakukan pemetaan diagram kelas perancangan kelas-kelas entitas menjadi tabel relasional. Terdapat 21 tabel yang dibuat untuk kebutuhan sistem. Tabel tersebut adalah tabel administrator, asistenpraktikum, berita, hari, haripraktikum, instruktur, instrukturmatakuliah, jadwalpraktikum, jampraktikum, kelaspraktikum, mahasiswa, matakuliah, modulpraktikum, penggantianjadwal, pengguna, pernyataanasisten, pesertamatakuliah, pesertapraktikum, ruang, tahunajaran dan usulanpraktikum.

Implementasi antarmuka dilakukan sesuai dengan perancangan interaksi. Antarmuka untuk use case Menyeleksi Asisten Praktikum ditunjukkan pada gambar 11.

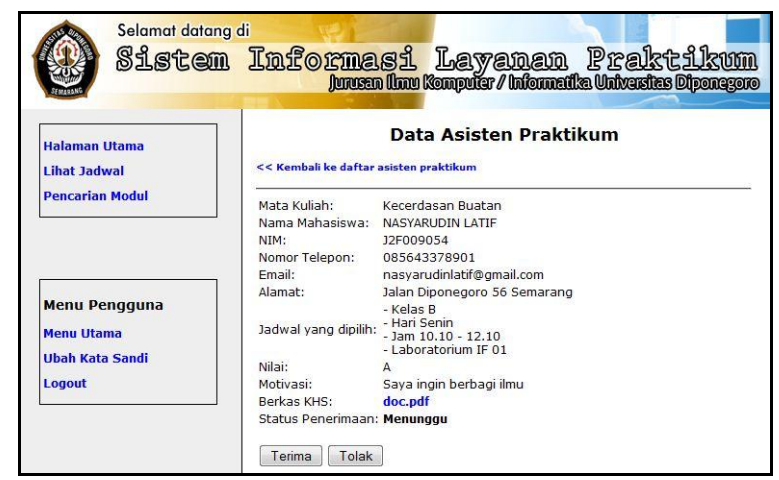

Gambar 11. Implementasi antarmuka use case Menyeleksi Asisten Praktikum

Setelah diimplementasikan, tahap selanjutnya adalah melakukan pengujian terhadap sistem informasi ini. Skenario pengujian Sistem Informasi Layanan Praktikum dibuat berdasarkan skenario use case yang telah dikembangkan pada tahap Analisis Interaksi. Rencana pengujian ini sudah mencakup tiga pengujian aplikasi berbasis web yang dikembangkan menggunakan kerangka kerja web engineering yaitu pengujian konten, pengujian navigasi dan pengujian fungsi.

Berdasarkan deskripsi dan hasil uji yang telah dilaksanakan, dapat dilihat bahwa semua pengujian telah diterima sehingga dapat disimpulkan bahwa Sistem Informasi Layanan Praktikum telah memenuhi semua use case yang telah didefinisikan sebelumnya.

\section{Kesimpulan}

Kesimpulan yang dapat diambil adalah bahwa pendekatan kerangka kerja web engineering mampu menghasilkan aplikasi berbasis web yang berkualitas baik dengan menyediakan langkah-langkah yang sesuai dengan kebutuhan suatu aplikasi berbasis web seperti Sistem Informasi Layanan Praktikum yang dibangun ini. Dengan menggunakan langkahlangkah pada kerangka kerja web engineering ini, dihasilkan Sistem Informasi Layanan Praktikum yang dapat membantu kelancaran proses pelaksanaan praktikum di lingkungan Jurusan Ilmu Komputer / Informatika Universitas Diponegoro. Selain itu, sistem informasi ini diharapkan dapat membantu pekerjaan masingmasing orang yang terlibat dalam kegiatan pelaksanaan praktikum di lingkungan Jurusan Ilmu Komputer / Informatika Universitas Diponegoro.

\section{Daftar Pustaka}

[1] Leman, Metodologi Pengembangan Sistem Informasi, Jakarta, Elex Media Computindo, 1998.

[2] Pressman R., dan Lowe D., Web Engineering: A Practitioner's Approach, New York, McGraw-Hill, 2009.

[3] Weisfeld, M., The Object-Oriented Thought Process, Third Edition, Pearson Education, 2005.

[4] Booch G., Rumbaugh J., dan Jacobson I., The Unified Modeling Language User Guide Second Edition, Addison Wesley Professional, 2005.

[5] Wahli, U., dkk, Servlet and JSP Programming, New York, IBM, 2000.

[6] Brown D., Davis C. M., dan Stanlick S., Struts 2 In Action, Greenwich, Manning, 2008.

[7] Suehring, S., MySQL Bible, New York, Wiley Publishing,, 2002. 